\title{
Assessment of Radish (Raphanus sativus L.) Cultivars for its Yield and Yield Attributing Characters at Central Mid-Hill (Kathmandu Valley) Conditions of Nepal
}

\author{
Surendra Lal Shrestha *, Dipendra Ghimire, Yadav Kumar Shrestha and Ishwori Prasad Gautam \\ National Horticulture Research Center, Khumaltar, Lalitpur \\ "Corresponding Author's Email: shsurendra@hotmail.com \\ "Orcid ID: https://orcid.org/0000-0003-1109-6514
}

Received on: 30 September 2020 , Revised on:21 April 2021, Accepted on: 22 April 2021

\begin{abstract}
A varietal study on five open pollinated cultivars of Radish viz Mino Early, Okura, Pusa Chetki, Forty Days and Miyasige with an objective to find the most superior variety was conducted at Horticultural Research Division, Khumaltar, Lalitpur in winter season for 3 years from 2016 in consecutive years. Mino Early and Forty Days are widely adopted varieties and kept as local check varieties. The trial was conducted under Randomized Complete Block Design (RCBD) with four replications. Out of the five cultivars, Okura gave significantly the highest of Root wt. (326 g), Root yield (53.85 t/ha), Root length $(25.5 \mathrm{~cm})$, Root diameter $(53.9 \mathrm{~mm})$, and Leaf wt per plant. ( $268 \mathrm{~g})$, Days to harvest (63 days) followed by Miyasige which had Root wt $(259 \mathrm{~g})$, Root length $(23.4 \mathrm{~cm})$ Root diameter $(51.9 \mathrm{~mm})$, Days to harvest (66 days). Okura had 49 percent yield increment followed by Miyasige with 21.9 percent as compared to Mino Early. Hence, these two cultivars are found superior and recommended for cultivation in central mid-hills like Kathmandu valley conditions in Nepal.
\end{abstract}

Keywords: Cultivars, mid-hills, promising, root yield, yield increment

\section{Introduction:}

Radish (Raphanus sativusL.) belongs to the family Brassicaceaeand is one of the most popular herbaceous root vegetable crops throughout the world which is mainly grown for its freshly edible roots. The hypocotyls and enlarged roots of radish are consumed basically for salad and cooking and are also rich in vitamins and minerals. It has got refreshing and diuretic property. In homeopathy, it is used for neurological problem, headache, sleeplessness and chronic diarrhea. The roots are also useful in urinary problems and piles. Radish can be useful as companion plants for several other crops because their pungency odour deters some insect pests such as aphid, cucumber beetle, tomato hornworm, squash bugs and ants. Gruver et al.,(2016) reported that the cultivation of radish reduces root knot nematodes (Meloidogyne incognita) and soybean cyst nematodes (Heterodera glycines). They also reported that cultivation of radish performs several valuable functions of cover crop such as provide soil cover, scavenge nutrients, suppress weeds, improve the soil by infiltration, increase porosity of soil and surface drainage. 
In Nepal, it is widely grown all over the country as a winter season vegetable crop but in context of hilly region it is grown throughout the year, especially in summer season, and brings lucrative returns to the farmers (Anon., 2016). It ranks third position among vegetable crops both in area and production after cauliflower and cabbage. The total area, production and productivity of radish is $16916 \mathrm{ha}, 268119 \mathrm{mt}$ and 15.9 t/ha, respectively and share about $6.02 \%$ area, $6.82 \%$ production among the major vegetables grown in the country (MoALD, 2016). The popularity of radish in Nepal could be due to its wider climatic adaption, easy cultivation method, suitable for mix and intercropping with cereals and other vegetables, short harvesting period and wider range of uses.

Nepal released only four cultivars of radish before 1994 and registered 2 open pollinated and 8 hybrid cultivars thereafter for production in different agroecological conditions (SQCC, 2019). However, the national productivity of radish is only $14.96 \mathrm{t} / \mathrm{ha}$, whereas productivity of improved cultivars have an encouraging yield potentiality of about 25-40 t/ha (Gautam and Khatiwada, 1997). There is no sufficient study on selection of suitable varieties of radish after 1994. Considering this, Horticulture Research Division have started varietal evaluation study in this crop for selection of high yielding cultivars in specific location in changing climatic conditions.

The popularity of seed production of Radish in Nepal has reached to a commercial level which could be due to its wider range of uses, wider climatic adaption and easy cultivation. Here the main objective of this trial was to find out the most promising cultivar of the radish.

Fertilizer trial on radish conducted at Lumle Agriculture Centre, Kaski at an altitud 1750 masl for off-season production showed that the radish variety Tokinashi was found to be suitable variety to be grown for the off seasonal production of radish (Jaiswal et al. 1995). In another study performed by Sharma et al., (2016) at Uttarkhanda Long white was found to be superior in its overall performance compared to the other 4 varieties viz. Green Neck, Snow White, Forty Days and Red Radish.

From a simple screening technique for identification of salt tolerant and salt sensitive radish genotypes conducted in Pakistan, Ayyub et al. (2016) found Laal-Pari and Forty Days as two radish genotypes that exhibited the best performance in all the observed morphological, physiological and ionic parameters and categorized them as salt tolerant genotypes.

In the esearch conducted by Dongarwar et al. (2018) in black soils of Maharashtra, India, Arka Nishant exhibited best performance on traits like root-shoot ratio, root diameter, root yield per plot, maximum moisture and ascorbic acid content compared to six other varieties.

\section{Materials and Methods}

The present experiment was conducted at the Horticulture Research Division farm Khumaltar, Lalitpur in winter season for three consecutive years in 2016 to 2018. Five open pollinated cultivars of Radish (Mino Early, Okura, Pusa Chetki, Forty Days and Miyasige) were evaluated.

Mino Early: A popular and released radish variety in 1990 AD in Nepal. Its root is long, white in color, tapering to the apex and sweet and pungent in taste. Leaf is serrated, dark green and horizontal spreading recommended for cultivation in terai to high hills.

Forty Days: A popular and released radish variety in 1994 AD in Nepal. It is early maturing variety, short and thick white root, root tip not straight, sweet taste, green leaves without serrated.

Pusa Chetki: Early maturing tropical radish variety. Roots are short, white, and sweet with mild pungent taste. Green leaves without serrated.

Okura: Japan origin, medium maturing short and thick white root, crispy and sweet taste, serrated green leaves.

Miyasige: Japan origin, medium maturing short, oblong and thick white root with green top, crispy and sweet taste, serrated green leaves.

The trial was conducted in a randomized complete block design (RCBD) with four replications where the plot size was $3.15 \mathrm{~m}^{2}(2.1 \mathrm{~m} \times 1.5 \mathrm{~m})$ with one bed/ plot, 7 rows in a bed at $30 \mathrm{~cm}$ apartand plant to plant $15 \mathrm{~cm}$ with 10 plants per row, counting a total of 70 plants per plot. There were 40 experimental plants in each plot.Seeds were sown on last week of October. $\mathrm{N}_{2}: \mathrm{P}_{2} \mathrm{O}_{5}: \mathrm{K}_{2} \mathrm{O}$ in the rateof 100:50:50 kg/ha and20-ton FYM/ha of compost was applied as a basal dose during field preparation. Additional $50 \mathrm{~kg}$ of $\mathrm{N}_{2}$ was applied as top dressing. Minimum insecticide and fungicide were sprayed. 
Marketableroots were harvested frequently and their number and weight were recorded in each harvest. Plant uniformity and vigor were recorded six weeks after seed sowing in 1 to 5 scale (1: unacceptable to 5: excellent). Root size (length, width) was measured at harvested time with 8 roots per plot and calculated average. Likewise, insect (aphid, leaf eating caterpillar) and disease (alternaria leaf spot) were recorded at different stages in 1 to 9 scales (1: no any symptom, 9: heavy damage.Number of leaves per plant was recorded from randomly selected 5 observational plants per plot and mean was calculated. Likewise, plant weight was measured individually with five plants per plot. Total number and total weight of roots per plot was calculated by adding all the harvested roots at different times. Yield was calculated based on theplot yield. Similarly, among the total length of the individual root, portion above the soil and under the soil was measured with ten roots and calculated ratio between above and under the soil. Beside this, ratio between root and shoot was calculated by dividing ten individual plant's leaves and root.

The data obtained for different parameters were statistically analyzed through MSTATC program to find out the significance difference of varieties on yield and yield contributing characters of radish.

\section{Results and Discussion}

\section{Number of leaves/plant and Leaf weight/plant}

Cumulative mean of Number of leaves per plant among the cultivars are significantly different. Okura (23.6) had significantly higher Number of leaves per plant as compared to Pusa Chetki (13.7) and, Forty Days (15.2) but at par with Mino Early (21) and Miyasige (19.3). In all the tested years, significant result was obtained with similar trend in Number of leaves/plantamong cultivars (Table 1). TheNumber of leaves per plant has also beenreflected in Root weight and Root yield i.e. cultivar Okura had higher mean Root weight and Root yield. Research conducted by Ola et al., (2018) in Garhawal hills found maximum number of leaves in Cv. Snow White. Variation in Number of leaves in radish cultivars might be due to difference in genetic make up of the cultivars and the environmental factors. Similar results were also reported by Naseeruddin et al., (2014).

Similarly, effect of cultivars onLeaf weight per plant was significant. The cultivar Okura (268 g) had significantly higher Leaf weight per plant as compared to Pusa Chetki (140 g) and Forty Days (129 g) and at par with Mino Early (236 g) and Miyasige (204 g). The trend is similar in all the tested years (Table 1).

Table 1: Number of leaves/plant and Leaf weight/plant of Radish cultivars at Khumaltar, Lalitpur (2016, 2017 \& 2018)

\begin{tabular}{|l|c|c|c|c|c|c|c|c|}
\hline \multicolumn{1}{|c|}{ Cultivars } & \multicolumn{4}{c|}{ Number of leaves/plant } & \multicolumn{4}{c|}{ Leaf weight/plant (g) } \\
\hline Years & 2016 & 2017 & 2018 & C. mean & 2016 & 2017 & 2018 & C.Mean \\
\hline Mino Early & 16.5 & 19.9 & 26.6 & $21.0 \mathrm{ab}$ & 188 & 154 & 367 & $236^{\text {ab }}$ \\
\hline Okura & 15.9 & 25.6 & 29.2 & $23.6 \mathrm{a}$ & 131 & 214 & 459 & $268^{\mathrm{a}}$ \\
\hline Pusa Chetki & 13.0 & 16.8 & 11.2 & $13.7 \mathrm{c}$ & 78 & 160 & 182 & $140^{\mathrm{b}}$ \\
\hline Forty Days & 14.4 & 14.4 & 16.8 & $15.2 \mathrm{bc}$ & 101 & 123 & 162 & $129^{\mathrm{b}}$ \\
\hline Miyasige & 14.4 & 23.8 & 19.8 & $19.3 \mathrm{abc}$ & 174 & 150 & 289 & $204^{\text {ab }}$ \\
\hline GM & 14.84 & 20.06 & 20.72 & 18.55 & 134.4 & 160.2 & 291.6 & 195.5 \\
\hline CV\% & 13.3 & 15.22 & 10.06 & 19.78 & 24.9 & 41.02 & 34.91 & 32.38 \\
\hline F-test & $\mathrm{ns}$ & $* *$ & $* *$ & $*$ & $*$ & $\mathrm{~ns}$ & $\mathrm{~ns}$ & $*$ \\
\hline LSD $(0.05)$ & - & 2.77 & 5.78 & 6.91 & 51.5 & - & - & 119.2 \\
\hline
\end{tabular}

ns-non significant *- Significant **-Highly significant,GM= Grand mean 


\section{Plant weight and Days to harvest}

Varietal difference on Plant weight was not significant. However,Okura had the highest Plant weight (754 g) followed by Mino Early (576 g) and Miyasige (555 g) respectively. However, it was significant in 2016 and 2017 (Table 2).

Effect of cultivars on cumulative mean Days to harvest was significant where Pusa Chetki (51 days) and Forty Days (51 days) became ready to harvest significantly earlier as compared to rest of the cultivars; Mino Early (67.5 days), Okura (63.5 days) and Miyasige (66.5 days) (Figure 1). Hence, Okura became ready to harvest 12 days later and Miyasige 14 days later compared to Pusa Chetki and Forty Days harvest (Figure 1). Days to harvest are correlated to Root yield. However, Okura gave almost double yield in 12 additional days compared to Pusa Chetki and Forty Days. The data in respect to Number of days required to harvesting and attainedible size, indicated thatit was varied from 5167 days, the variation in harvesting date among the cultivars is due to different genetic make up of the cultivars. The similar variations in harvesting days among different cultivars was reported by Bhatti et al. (1983) in radish.
Table 2: Combined mean of Plant weight of Radish cultivars at Khumaltar (2016, 2017 \& 2018)

\begin{tabular}{|l|l|l|l|l|}
\hline \multicolumn{1}{|c|}{ Cultivars } & \multicolumn{5}{|c|}{ Plant weight(g) } \\
\hline \multicolumn{1}{|c|}{ Year } & $\mathbf{2 0 1 6}$ & $\mathbf{2 0 1 7}$ & $\mathbf{2 0 1 8}$ & C Mean \\
\hline Mino Early & 414 & 390 & 923 & 576 \\
\hline Okura & 450 & 533 & 1278 & 754 \\
\hline Pusa Chetki & 188 & 343 & 976 & 502 \\
\hline Forty Days & 219 & 329 & 525 & 358 \\
\hline Miyasige & 426 & 455 & 785 & 555 \\
\hline GM & 339.4 & 410.1 & 897.6 & 548.9 \\
\hline CV\% & 27.70 & 25.1 & 41.91 & 24.95 \\
\hline F-test & $* *$ & $* *$ & ns & ns \\
\hline LSD $(0.05)$ & 145 & 93.36 & - & - \\
\hline
\end{tabular}

ns-non-significant *- Significant **-Highly significant

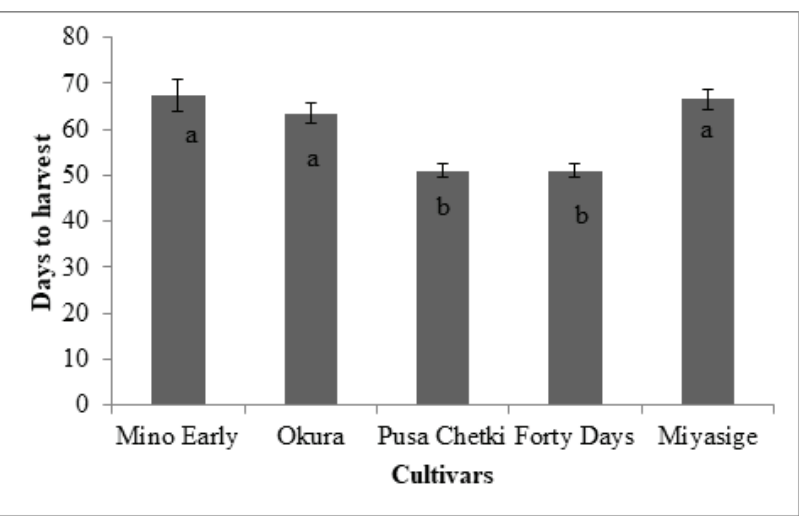

Figure 1: Combined mean Days to harvest of five Radish cultivars (2017 \& 2018)

\section{Ratio of root to leaf}

Varietal effect of cumulative mean of ratio of Root to leaf is not significant and also in all the tested years. However, Pusa Chetki has higher Root to leaf ratio (2.17) followed by Okura (1.91) and Miyasige (1.79) (Table 3).

Table 3:Combined mean of ratio of Root to leaf and Leaf length of Radish cultivars at Khumaltar (2016, 2017 \& 2018)

\begin{tabular}{|l|c|c|c|c|c|c|c|}
\hline \multicolumn{1}{|c|}{ Cultivars } & \multicolumn{4}{c|}{ Ratio of root to leaf } & \multicolumn{3}{c|}{ Leaf length (cm) } \\
\hline \multicolumn{1}{|c}{ Year } & $\mathbf{2 0 1 6}$ & $\mathbf{2 0 1 7}$ & $\mathbf{2 0 1 8}$ & C Mean & $\mathbf{2 0 1 6}$ & $\mathbf{2 0 1 8}$ & C Mean \\
\hline Mino Early & 1.88 & 1.53 & 1.65 & 1.46 & 46.2 & 42.3 & $44.2^{\text {ab }}$ \\
\hline Okura & 2.54 & 1.49 & 1.81 & 1.91 & 44.9 & 40.5 & $42.7^{\mathrm{b}}$ \\
\hline Pusa Chetki & 1.41 & 1.14 & 3.95 & 2.17 & 49.2 & 45.1 & $47.1^{\mathrm{ab}}$ \\
\hline Forty Days & 1.18 & 1.67 & 2.23 & 1.69 & 32.1 & 32.8 & $32.4^{\mathrm{c}}$ \\
\hline Miyasige & 1.42 & 2.03 & 1.90 & 1.79 & 48.0 & 50.1 & $49.0^{\mathrm{a}}$ \\
\hline GM & 1.55 & 1.57 & 2.31 & 1.80 & 44.08 & 42.19 & 43.12 \\
\hline CV\% & 19.79 & 43.6 & 52.01 & 40.28 & - & 9.45 & 5.04 \\
\hline F-test & $* *$ & $\mathrm{~ns}$ & $\mathrm{~ns}$ & $\mathrm{~ns}$ & - & $\mathrm{ns}$ & $* *$ \\
\hline LSD $(0.05)$ & 0.94 & - & - & - & - & - & 6.039 \\
\hline
\end{tabular}




\section{Root above and under soil and its ratio}

Effect of cultivars on cumulative mean of root above soil is not significantly different but it was significant in 2017. The root growth and yield was higher in 2017 due to favorable weather as compared to 2016, may be the reason why it was significant in 2017 due to expression of its potentiality (Table 4).

Effect of cultivars on cumulative mean of root under soil is significant and also in both the years. Cultivar Okura $(17.4 \mathrm{~cm})$ is at par to Miyasige $(16.2 \mathrm{~cm})$ and Mino Early $(18.6 \mathrm{~cm})$ had significantly longer root under soil as compared to Pusa Chetki $(12.2 \mathrm{~cm})$ and
Forty Days $(12.5 \mathrm{~cm})$. Same trend was observed in both the years (Table 4).

As far as ratio of above and under soil is concerned, it is significant among the varieties in cumulative mean in both the years. Cultivar Pusa Chetki (0.353) and Forty Days (0.370) higher ratio which is at par to Miyasige (0.266) and significantly higher than Mino Early and Okura (0.16) (Table 4). It showed that early maturing varieties had higher ratio as compared to medium maturing varieties. It also reflected in yield that lower the ratio higher the yield. Reason behind may be as longer the root under soil, more to absorb nutrients from the soil and good nutrition for the plant.

Table 4: Combined mean of Root length above and under soil surface and their ratioamongRadish cultivars at Khumaltar (2016 \& 2017)

\begin{tabular}{|l|l|l|l|l|l|l|l|l|l|}
\hline \multicolumn{1}{|c|}{ Cultivars } & \multicolumn{3}{|c|}{ Root length above soil (cm) } & \multicolumn{3}{c|}{ Root length under soil (cm) } & \multicolumn{3}{c|}{ Ratio (above: under soil) } \\
\hline \multicolumn{1}{|c}{ Year } & $\mathbf{2 0 1 6}$ & $\mathbf{2 0 1 7}$ & $\mathbf{C}$ Mean & $\mathbf{2 0 1 6}$ & $\mathbf{2 0 1 7}$ & $\mathbf{C}$ Mean & $\mathbf{2 0 1 6}$ & $\mathbf{2 0 1 7}$ & C Mean \\
\hline Mino Early & 2.8 & 3.4 & 3.1 & 16.3 & 21.0 & $18.6^{\mathrm{a}}$ & 0.172 & 0.164 & $0.168^{\mathrm{b}}$ \\
\hline Okura & 2.5 & 4.0 & 3.2 & 15.5 & 19.4 & $17.4^{\mathrm{ab}}$ & 0.161 & 0.212 & $0.186^{\mathrm{b}}$ \\
\hline Pusa Chetki & 2.7 & 6.3 & 4.5 & 8.8 & 15.6 & $12.2^{\mathrm{c}}$ & 0.307 & 0.399 & $0.353^{\mathrm{a}}$ \\
\hline Forty Days & 2.9 & 6.7 & 4.8 & 9.9 & 15.1 & $12.5^{\mathrm{c}}$ & 0.293 & 0.446 & $0.370^{\mathrm{a}}$ \\
\hline Miyasige & 3.4 & 4.7 & 4.0 & 13.0 & 19.5 & $16.2^{\mathrm{b}}$ & 0.261 & 0.249 & $0.255^{\text {ab }}$ \\
\hline GM & 2.86 & 5.03 & 3.94 & 12.7 & 18.14 & 15.41 & 0.244 & 0.294 & 0.266 \\
\hline CV\% & 10.91 & 37.52 & 25.96 & 16.9 & 16.50 & 5.60 & 16.52 & 36.97 & 18.51 \\
\hline F-test & $*$ & $* *$ & $\mathrm{~ns}$ & $* *$ & $* *$ & $* *$ & $* *$ & $* *$ & $*$ \\
\hline LSD $(0.05)$ & 0.99 & 1.712 & - & 3.3 & 2.714 & 2.395 & 0.068 & 0.099 & 0.124 \\
\hline
\end{tabular}

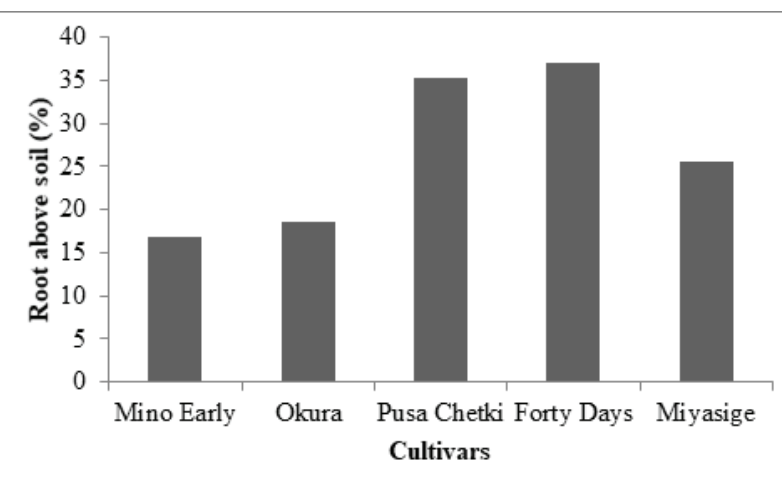

Figure 2: Portion of Root length above the soil surface among Radish cultivars at Khumaltar (2016 \& 2017)

\section{Root length (cm) and Root diameter (mm)}

Combined mean of Root length of the tested cultivars have significant different. Cv. Okura had significantly longer Root length $(25.5 \mathrm{~cm})$ as compared to Forty Days $(21.1 \mathrm{~cm})$ and Miyasige $(23.4 \mathrm{~cm})$ and Pusa
Chetki $(22.7 \mathrm{~cm})$ is at par with Mino Early $(24.7 \mathrm{~cm})$. But among the tested years significant difference was obtained only in 2016 . The Root length among cultivars variedfrom $25.5-21.1 \mathrm{~cm}$. However, the trend is similar (Table 5). Medium long root is important character regarding root quality and is useful to classify the cultivars for consumer acceptability. Environmental factors, soil conditions and genetic factors strongly effectRoot length. Similar results in variation among the cultivars were found by Deotale et al., (1994).

Cumulative mean of the Root diameter among the cultivars are significantly different where cv. Okura had significantly wider Root diameter $(53.9 \mathrm{~mm})$ as compared to Mino Early $(45.1 \mathrm{~mm})$ and Pusa Chetki $(45.3 \mathrm{~mm})$ but at par to Forty Days $(47.9 \mathrm{~mm})$ and Miyasige $(51.9 \mathrm{~mm})$. Among the years tested Root diameter difference of cultivars was significant only in 2016 and 2017 (Table 5). 
Table 5: Combined mean of Root length and Root diameter of radish cultivars at Khumaltar, Lalitpur (2016, 2017\& 2018)

\begin{tabular}{|c|c|c|c|c|c|c|c|c|}
\hline \multirow{2}{*}{$\begin{array}{c}\text { Cultivars } \\
\text { Year }\end{array}$} & \multicolumn{4}{|c|}{ Root length (cm) } & \multicolumn{4}{|c|}{ Root diameter(mm) } \\
\hline & 2016 & 2017 & 2018 & C Mean & 2016 & 2017 & 2018 & C Mean \\
\hline Mino Early & 19.1 & 24.4 & 30.5 & $24.7^{\mathrm{ab}}$ & 42.3 & 40.2 & 52.5 & $45.1^{\mathrm{b}}$ \\
\hline Okura & 18.0 & 23.4 & 35.0 & $25.5^{\mathrm{a}}$ & 49.6 & 46.9 & 65.2 & $53.9^{\mathrm{a}}$ \\
\hline Pusa Chetki & 19.5 & 21.9 & 26.7 & $22.7^{\mathrm{ab}}$ & 35.5 & 47.1 & 53.2 & $45.3^{b}$ \\
\hline Forty Days & 12.8 & 21.9 & 28.6 & $21.1^{\mathrm{b}}$ & 38.6 & 51.5 & 53.8 & $47.9^{\mathrm{ab}}$ \\
\hline Miyasige & 16.4 & 24.2 & 29.7 & $23.4^{\mathrm{ab}}$ & 48.0 & 49.6 & 58.1 & $51.9^{\mathrm{ab}}$ \\
\hline GM & 17.16 & 23.17 & 30.12 & 23.46 & 42.8 & 47.05 & 56.56 & 48.8 \\
\hline CV\% & 14.1 & 15.59 & 13.05 & 9.34 & 10.6 & 15.16 & 8.99 & 8.58 \\
\hline F-test & $*$ & ns & ns & $*$ & $* *$ & $*$ & ns & $*$ \\
\hline $\operatorname{LSD}(0.05)$ & 3.4 & - & - & 4.129 & 7.8 & 6.469 & - & 7.88 \\
\hline
\end{tabular}

ns-non-significant *- Significant **-Highly significant

\section{Root weight and Root yield (Average Root weight and Root yield)}

Average Root weight difference was significant among the cultivars. Cv. Okura (326.3 g), Miyasige (259 g) and Mino Early (240 g) had significantly higher Root weight as compared to Pusa Chetki (160.6 g) and Forty Days (187 g) (Table 6). It wassignificantin all the tested three years with same trend. Yield is supposed to be reflections of the yield components where higher the root weightshigher would be the yield. Cultivars having average weight less than $500 \mathrm{~g}$ (250 to $350 \mathrm{~g}$ ) is more preferred by the consumers in Nepal. The cultivar Okura recorded maximum Root yield(53.58 t/ha) of optimum size and it was sigificantly superior over rest of cultivars followed by Miyasige with (43.80t/ha) and Mino Early with (35.93t/ha). Theminimum root yield was $(27.5 \mathrm{t} / \mathrm{ha})$ recorded in cultivar Pusa Chetki (Table 6). The yield is the result of interaction of the genotype to a given agro-climatic and management factors. The yield variations among these five cultivars may be considered as cultivars difference, as all these cultivars are tested under same soil, management and similar agro-climatic conditions. The variations in yield among the cultivars were also found by Khokhar et al., (1987). Poudel et al., (2018) reported that Okura recorded maximum root yield in eastern hill conditions. The higher yielder cv. Okura had also higher number of leaves and leaves weight per plant. The higher yield attributing character is also correlated with Number of leaves on it, which could have synthesized more food materials and supplied to the roots, that might have resulted in increasing the weight and diameter of the roots and ultimately resulted in higher root yield. These results were inconfirmity with finding of Singh and Taj (2005), Deotale et al., (1994) in radish.

If we calculate yield in yield increment percent as compared to widely grown popular radish variety Mino Early, the highest yield increment (49 percent) was obtained from Okura followed by Miyasige (21.9\%) (Figure.3). These two cultivars are very superior than Forty Days that is also widely grown as early maturing variety in Nepal.

Table 6 : Root weight and Root yield of radish cultivars at Khumaltar, Lalitpur (2016, 2017 \& 2018)

\begin{tabular}{|l|l|l|l|l|l|l|l|l|}
\hline \multicolumn{1}{|c|}{ Cultivars } & \multicolumn{4}{c|}{ Root weight (g) } & \multicolumn{4}{c|}{ Root yield(t/ha) } \\
\hline \multicolumn{1}{|c|}{ Year } & $\mathbf{2 0 1 6}$ & $\mathbf{2 0 1 7}$ & $\mathbf{2 0 1 8}$ & \multicolumn{1}{c|}{ Mean } & $\mathbf{2 0 1 6}$ & $\mathbf{2 0 1 7}$ & $\mathbf{2 0 1 8}$ & \multicolumn{1}{c|}{ Mean } \\
\hline Mino Early & 226 & 236 & 258 & $240^{\mathrm{b}}$ & 21.51 & 47.16 & 39.12 & $35.93^{\mathrm{bc}}$ \\
\hline Okura & 320 & 319 & 340 & $326.3^{\mathrm{a}}$ & 46.12 & 63.76 & 51.67 & $53.85^{\mathrm{a}}$ \\
\hline Pusa Chetki & 111 & 183 & 188 & $160.7^{\mathrm{c}}$ & 15.23 & 36.52 & 30.75 & $27.50^{\mathrm{c}}$ \\
\hline Forty Days & 119 & 206 & 236 & $187^{\mathrm{c}}$ & 13.83 & 41.13 & 39.04 & $31.33^{\mathrm{c}}$ \\
\hline
\end{tabular}




\begin{tabular}{|l|l|l|l|l|l|l|l|l|}
\hline \multicolumn{1}{|c|}{ Cultivars } & \multicolumn{4}{c|}{ Root weight (g) } & \multicolumn{4}{c|}{ Root yield(t/ha) } \\
\hline \multicolumn{1}{|c}{ Year } & $\mathbf{2 0 1 6}$ & $\mathbf{2 0 1 7}$ & $\mathbf{2 0 1 8}$ & \multicolumn{1}{c|}{ Mean } & $\mathbf{2 0 1 6}$ & $\mathbf{2 0 1 7}$ & $\mathbf{2 0 1 8}$ & \multicolumn{1}{c|}{ Mean } \\
\hline Miyasige & 252 & 305 & 301 & 259 ab & 28.46 & 60.91 & 42.05 & $43.80^{\text {b }}$ \\
\hline GM & 205.6 & 249.5 & 264.6 & 240 & 25.03 & 49.90 & 40.53 & 38.4 \\
\hline CV\% & 31.3 & 19.26 & 26.94 & 9.59 & 18.6 & 19.26 & 23.57 & 11.81 \\
\hline F-test & $*$ & $* *$ & $*$ & $*$ & $* *$ & $* *$ & $*$ & $* *$ \\
\hline LSD $(0.05)$ & 99.2 & 74.03 & 109.9 & 43.32 & 7.16 & 14.81 & 14.71 & 8.555 \\
\hline
\end{tabular}

*-Significant **-Highly significant

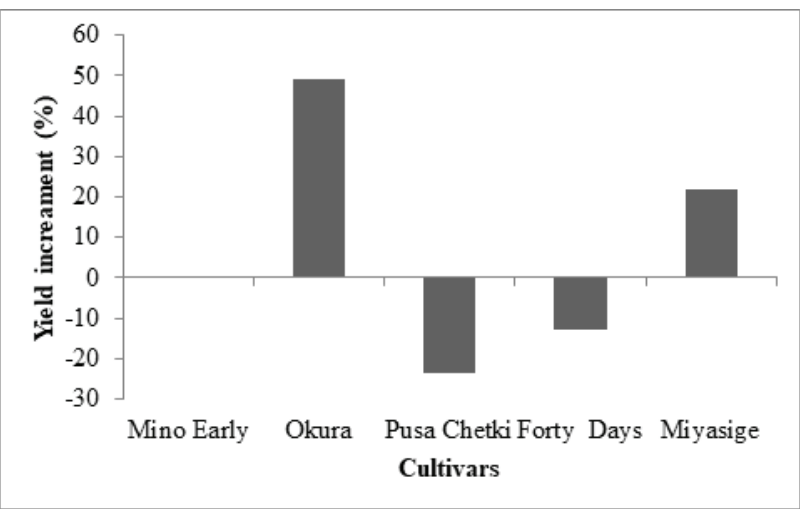

Figure 3: Percent yield increment of Okura and Miyasige as compared to Mino Early

\section{Insect pest and disease}

Leaf spot(Alternaria raphaniL.)was the major fungal disease in radish crop. Okura (2.2) was significantly less infected with this disease as compared to Pusa Chetki. In all the cultivars, disease occurrence was higher in 2018 as compared to 2017 (Table 7). It may be due to weather condition because in 2018 , it was cooler and higher relative humidity due to rain as compared to 2017. Similarly, insect damage was also lower in 2017 as compared to 2018 however; there was no significant difference among the varieties (Table 7).

Table 7: Combined mean of Leaf spot and Insect damage among Radish cultivars at Khumaltar (2017 \& 2018)

\begin{tabular}{|l|c|c|c|c|c|c|}
\hline \multicolumn{1}{|c|}{ Cultivars } & \multicolumn{3}{c|}{ Leaf spot (1-9) $^{\mathrm{x}}$} & \multicolumn{3}{c|}{ Insect damage (1-9) $^{\mathrm{x}}$} \\
\hline \multicolumn{1}{|c|}{ Year } & $\mathbf{2 0 1 7}$ & $\mathbf{2 0 1 8}$ & C Mean & $\mathbf{2 0 1 7}$ & $\mathbf{2 0 1 8}$ & C Mean $^{-1}$ \\
\hline Mino Early & 2.0 & 4.0 & $3.0^{\mathrm{ab}}$ & 1.2 & 3.7 & 2.5 \\
\hline Okura & 1.5 & 3.0 & $2.2^{\mathrm{b}}$ & 1.5 & 3.2 & 2.4 \\
\hline Pusa Chetki & 2.5 & 4.2 & $3.3^{\mathrm{a}}$ & 1.7 & 2.7 & 2.2 \\
\hline Forty Days & 2.0 & 3.7 & $2.8^{\mathrm{ab}}$ & 1.5 & 3.5 & 2.5 \\
\hline Miyasige & 1.5 & 4.2 & $2.8^{\mathrm{ab}}$ & 1.2 & 4.0 & 2.6 \\
\hline GM & 1.90 & 3.82 & 2.86 & 1.45 & 4.22 & 2.42 \\
\hline CV\% & 51.75 & 25.65 & 11.65 & 40.31 & 17.35 & 20.56 \\
\hline F-test & $\mathrm{ns}$ & $\mathrm{ns}$ & $*$ & $\mathrm{~ns}$ & $\mathrm{~ns}$ & $\mathrm{~ns}$ \\
\hline LSD (0.05) & - & - & .925 & - & & - \\
\hline
\end{tabular}

x 1-Resistant 9-highly susceptible

\section{Conclusion}

Among the five tested cultivars of Radish it was found that the variety Okura showed promising results in terms of various characteristics such as Root wt.(326.3g), Root length $(25.5 \mathrm{~cm})$, Root diameter $(53.9 \mathrm{~mm})$, Root yield (53.85t/ha), Number of leaves/plant (23.6), Plant weight (754 g), Days to harvest (63.5) and Leafweight/plant (268 g)followed by Miyasige with Root wt. (259 g), Root length $(23.4 \mathrm{~cm})$, Root diameter(51.9 mm), Root yield (43.80 t/ha), Number of leaves/plant (19.3), Plant weight (555gm), Days to harvest (66.5) andLeaf weight/plant (204gm)inthree consecutive years trial at Khumaltar, Lalitpur. The results showed that Okura followed by Miyasige are most superior varieties among the tested cultivars. So, these two cultivarscould be recommended for cultivation in the central mid-hill region such as Kathmandu valley or similar places in Nepal. 


\section{Acknowledgement}

Authors would like to acknowledge all the scientists, technical officers, technicians who were are directly or indirectly supported to conduct this research and Horticulture Research Division and NARC for providing fund to the conduct research.

\section{Declaration of conflict of interest and ethical approval}

S.L Shrestha involved in designing, conducting experiment, analyzing and interpreting the results and preparing manuscript. D. Ghimire and Y.K Shrestha involved in conducting study and manuscript preparation. I.P. Gautam involved in supervising the experimental work, providing guidelines for result interpretation and manuscript preparation

The authors declare no conflicts of interest regarding publication of this manuscript

\section{Reference:}

Anonymous, (2016). Annual Report. Nepal Agricultural Research Council (NARC). Horticulture Research Division, Khumaltar, Lalitpur, Nepal. NARC Publication Serial No. 00410223/2016/017. 82p.

Ayyub, C. M., Shaheen, M. R., Raza, S., Yaqoob, M. S., Qadri, R. W. K., Azam, M., ... \&Akhtar, N. (2016). Evaluation of different radish (Raphanus sativus) genotypes under different saline regimes. American Journal of Plant Sciences, 7(06), 894.

Bhatti, M. H., Ullah, H. I., Sharafat, K., \& Abdul, S. (1983). An evaluation of exotic and local cultivars of radish (Raphanus sativus). Pakistan Journal of Agricultural Research, 4(1), 17-21

Deotale, A. B., Belorkar, P. V., Badvaik, N. G., Patil, S. R., \& Rathod, J. R. (1994). Performance of some radish (Raphanus sativus L.) cultivars under Nagpur condition. J. Soil and Crops, 4(2), 120-121.

Dongarwar, L. N., Kashiwar, S. R., Ghawade, S. M., \& Dongarwar, U. R. (2018). Varietal Performance of Radish (Raphanus sativus L.) Varieties in Black Soils of Vidharbha-Maharashtra, India. Int. J. Curr. Microbiol. App. Sci, 7(1), 491-501.
Gautam, I. P., \& Khatiwada, P. P. (1997). Results on purification of Bhedetar Local radish (No. 205, pp. 1-6). Working paper.

Gruver, J., Weil, R. R., White, C., \& Lawley, Y. (2016). Radishes: A new cover crop for organic farming systems. Organic Agriculture, 20160226.

Jaiswal, J.P., Subedi, P.P., \& Gurung, H.M. (1995). Fertilizer Trial on Radish for Off-season production. Lumle Agriculture Centre, Kaski, Nepal. (LARC Working Paper No. 96/13).

Khokhar, K. M., Hussain, I., \& Qureshi, K. M. (1987). Performance of some early maturing radish cultivars in respect of yield and certain growth characters. Pakistan Journal of Agricultural Sciences (Pakistan).

MOAD. (2016). Ministry of Agriculture and Cooperatives. Agri-Business Promotion and Statistics Division, Singh Durbar, Kathmandu, Nepal. 212p.

Naseeruddin, K. H., Singh, V., \& Rana, D. K. (2014). Performance of different radish (Raphanus sativus L.) varieties suitable under garhwal himalaya region. Weekly Sci. Res. J, 2(12), 23217871.

Ola, A. L., Rana, D. K., \& Jhajhra, M. R. (2018). Evaluation of radish (Raphaanus sativus L) varieties under valley condition of Garhwal hills. Journal of Pharmacognosy and Phytochemistry, 7(1), 2740-2743.

Poudel, K., Karki, S., Sah, M. K., \& Mandal, J. L. (2018). Evaluation of radish (Raphanus sativus L.) genotypes in Eastern mid-hills condition of Nepal. World News of Natural Sciences, 19, 155159.

Sharma, S., Dhami, V., Tyagi., M. \& Singh, C.P. (2016). Morphological evaluation of radish (Raphanus sativus L.) varieties in foothill conditions of Uttarakhand. International Journal of Agriculture Sciences: 8(63):3591-3593

Singh, V.B.\& Taj, R.K. (2005).Evaluation of radish cultivars under rain fed conditions of Nagaland. Prog. Horti. 37 (1): $72-74$.

SQCC. (2019). Seed Quality Control Center. 2019. Notified and denotified varieties. Department of Agriculture, Ministry of Agriculture 